\title{
Production of Cell Wall Degrading Enzymes by Isolates of Bipolaris maydis, the Causative Agent of Maydis Leaf Blight of Maize
}

\author{
Nazia Manzar*, Abhijeet S. Kashyap and Pawan K. Sharma \\ ICAR-National Bureau of Agriculturally Important Microorganisms (ICAR-NBAIM), \\ Kushmaur, Mau Nath Bhanjan, Uttar Pradesh, India
}

*Corresponding author

\section{Keywords}

Amylase, Pectinase, Aggressiveness, Virulence, Bipolaris maydis, Biotic stresses

Article Info

Accepted:

15 November 2019

Available Online:

10 December 2019

\section{A B S T R A C T}

Bipolaris maydis is a phytopathogen of maize that causes maydis leaf blight or Southern corn leaf blight disease. The Biploaris maydis produce extracellular enzymes that degrade cellulose, pectin, amylose and amylopectin of the plant cell wall and helps in invasion and virulence of the phytopathogen in the infected tissue. Variations among the seven isolates of Bipolaris maydis were found for extracellular enzymatic activity in solid medium and the amylase activity showed the highest activity index. E15 isolate of Bipolaris maydis showed the highest amylase, pectinase and esterase activity, whereas, E27 isolate showed highest cellulase activity index as compared to other isolates. The results indicated the possible role of cell wall degrading enzymes in the aggressiveness, virulence and increase the disease incidence of the maydis leaf blight of maize.

\section{Introduction}

Maize is the third major staple food in India and due to its high efficiency; it is regarded as queen of the cereals. Maize is susceptible to so many foliar diseases and due to the biotic stresses, the grain yield reduces to a greater extent. Maydis leaf blight is one of the most serious foliar diseases of maize and is caused by Bipolaris maydis. The qualitative measurement of the extracellular enzymes is indicative of the physiological process of microbes. Extracellular enzyme production by the plant pathogenic fungi is the key factor for characterization of variability among the plant pathogenic fungus. The presence of enzymatic activity exhibited by the fungus helps it to degrade the plant cell wall and facilitates its entry and mycelia growth in plants and is an important factor for virulence in the plants. The main aim of the present investigation was to study the physiological variability based on the extracellular enzymatic production by the seven isolates of Bipolaris maydis. 


\section{Materials and Methods}

The extracellular enzymes activity by the Bipolaris maydis. were assessed in solid minimal medium containing $0.5 \mathrm{~g} \mathrm{KCl}, 1.5 \mathrm{~g}$ $\mathrm{KH}_{2} \mathrm{PO}_{4}, 6 \mathrm{~g} \mathrm{NaNO}, 0.5 \mathrm{~g} \mathrm{MgSO}_{4}, 0.01 \mathrm{~g}$ $\mathrm{FeSO}_{4}, 0.01 \mathrm{~g} \mathrm{ZnSO}_{4}$ and one liter distilled $\mathrm{H}_{2} \mathrm{O}$ and mycelial discs of $0.5 \mathrm{~cm}$ diameter of each isolate were transferred into Petri plates. These plates were incubated at $25^{\circ} \mathrm{C}$ for 5 days. The minimal medium were added with the enzyme substrate adjusted to $\mathrm{pH} 6$ as follow: pectin (1\%), carboxymethyl cellulose (CMC) $(1 \%)$, starch (1\%) and $\mathrm{CaCl}_{2} 0.01 \%$ with Tween $-80(1 \%)$ and adjusted to $\mathrm{pH} 6$ for pectinase, cellulase, amylase and esterase respectively. The enzymatic activity was observed after supplying the congo red solution for cellulase, $1 \%$ Ctab for pectinase, $1 \%$ Lugol(KI) for amylase and incubation at $4^{\circ} \mathrm{C}$ for $48 \mathrm{~h}$ for esterase respectively.

The ratio of mean halo diameter $(\mathrm{H})$ divided by the mean colony diameter(C) were used for quantification of enzyme activity.

\section{Statistical analysis}

Data obtained on various traits under laboratory were analyzed by Duncan's multiple range test (DMRT) and one-way analysis of variance (ANOVA) using Statistical Product and Service Solution (SPSS) version16.0 software Developed by SPSS Inc., now IBM SPSS and each experiment was replicated thrice. All results were expressed at $\mathrm{P}<0.05$ to compare difference among the treatment means.

\section{Results and Discussion}

The extracellular enzymes secreted by fungal plant pathogens induce virulence (Wanyoike et al., 2002 and Wubben et al., 2000). In phytopathogenic fungi, the pectinase enzyme played a key role for infection (Ten Have et al., 1998 and Valette-Collet et al., 2003). In this process, pectic enzymes caused pectin degradation and resulted in cell lysis, plant tissue maceration and degradation of cell wall components which ultimately resulted in penetration of fungi inside the infected host tissue (Ten Have et al., 2002 and Panda et al., 2004). In the current investigation, all the seven isolates showed pectinase, esterase, amylase and cellulase activities (Table 1 and Fig. 1). The highest pectinase activity $(\mathrm{H} / \mathrm{C}=1.36)$ was observed in $\mathrm{E} 15$ isolate and lowest was observed in $\mathrm{E} 7(\mathrm{H} / \mathrm{C}=1.09)$ isolate. Similar results have been reported earlier wherein $F$. culmorium and $F$. graminareaum produced pectinase enzyme that caused cell wall degradation to facilitate the pathogen entry in the infected tissue (Kang et al., 2000, Kang et al., 2000b and Wanyoike et al., 2002). Boccas et al., (1994) evaluated 248 isolates from coffee plant for assessing the production of extracellular enzymes and found that 119 isolates produced pectinase enzyme and 13 isolates were high producers of pectinase enzyme and most of them belonged to Aspergillus sp. and Penicillium sp.

The cellulase enzyme is produced by plant pathogenic fungus after appresorium formation (Deising et al., 1995 and Mendgen et al., 1996). Cellulase plays a major role in pathogenesis as it degrades the cellulose which is an important component of the plant cell wall and activates the process of infection, which leads to increase in virulence of the pathogen (Sipos et al., 2010, Zhang et al., 2014). In terms of cellulase activity, the isolate E27 showed highest index $(\mathrm{H} / \mathrm{C}=1.56)$ and the lowest was observed in E6 $(\mathrm{H} / \mathrm{C}=$ 1.06). 
Table.1 Extracellular enzymatic activity by Bipolaris maydis

\begin{tabular}{|c|c|c|c|c|}
\hline Isolates & Pectinase & Esterase & Amylase & Cellulase \\
\hline E6 & $1.21 \pm 0.02^{\mathrm{bc}}$ & $1.12 \pm 0.03^{\mathrm{d}}$ & $2.13 \pm 0.02^{\mathrm{c}}$ & $1.06 \pm 0.04^{\mathrm{c}}$ \\
\hline E7 & $1.09 \pm 0.02$ & $1.34 \pm 0.01^{\mathrm{b}}$ & $1.53 \pm 0.04^{\mathrm{e}}$ & $1.05 \pm 0.05^{\mathrm{c}}$ \\
\hline E10 & $1.24 \pm 0.02^{\mathrm{b}}$ & $1.23 \pm 0.01^{\mathrm{c}}$ & $1.57 \pm 0.04^{\mathrm{e}}$ & $1.18 \pm 0.05^{\mathrm{bc}}$ \\
\hline E15 & $1.36 \pm 0.02^{\mathrm{a}}$ & $1.40 \pm 0.01^{\mathrm{a}}$ & $4.10 \pm 0.11^{\mathrm{a}}$ & $1.25 \pm 0.04^{\mathrm{b}}$ \\
\hline E19 & $1.18 \pm 0.01^{\mathrm{cd}}$ & $1.12 \pm 0.02^{\mathrm{d}}$ & $1.79 \pm 0.02^{\mathrm{d}}$ & $1.14 \pm 0.04^{\mathrm{bc}}$ \\
\hline E25 & $1.11 \pm 0.01^{\mathrm{ef}}$ & $1.23 \pm 0.01^{\mathrm{c}}$ & $1.75 \pm 0.01^{\mathrm{d}}$ & $1.14 \pm 0.05^{\mathrm{bc}}$ \\
\hline E27 & $1.16 \pm 0.02^{\mathrm{de}}$ & $1.14 \pm 0.01^{\mathrm{d}}$ & $3.06 \pm 0.07^{\mathrm{b}}$ & $1.56 \pm 0.04^{\mathrm{a}}$ \\
\hline C.D. & 0.05 & 0.05 & 0.17 & 0.13 \\
\hline SE(m) & 0.02 & 0.02 & 0.06 & 0.04 \\
\hline C.V. & 2.42 & 2.16 & 4.26 & 6.27 \\
\hline
\end{tabular}

Fig.1 Production of extracellular enzymes by Bipolaris maydis on plates. Clear zones representing a) pectinase b) cellulase c) esterase and d) amylase activity shown by Bipolaris maydis
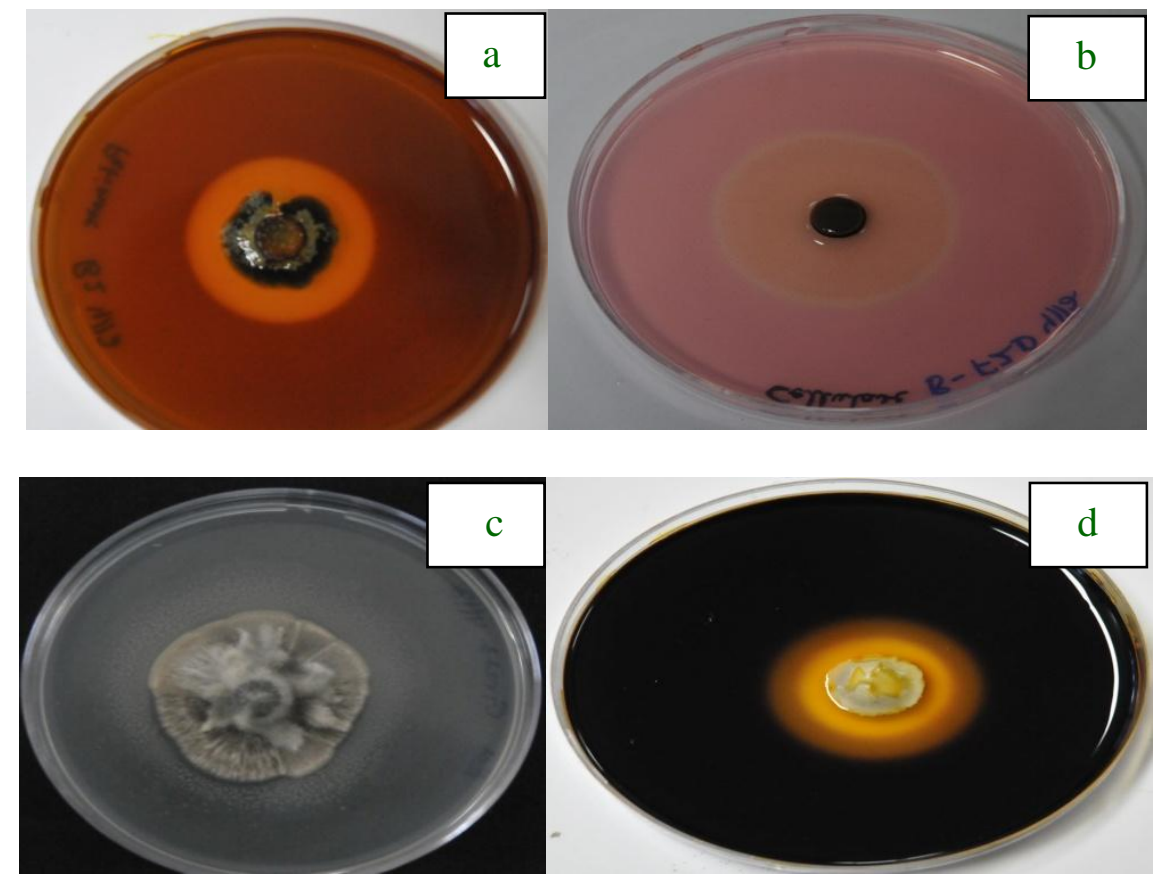

Similar results had been observed for the production of cellulase enzymes by Didymella bryoniae in cultures resulted to further decaying of the host tissue and correlated with disease severity(Zhang et al., 2014; Zhou et al., 2016).Cellulase production observed in culture of so many plant pathogenic fungi such as Colletotrichum acutatum (Fernando $e t$ al., 2001), Phaeosphaeria nodorum (Lalaoui et al., 2000), Fusarium sulphureum (Yang et al., 2012), Gaeumannomyces graminis (Dori et al., 1995) and Thanatephorus cucumeris (Jayasinghe et al., 2004; Zhao et al., 2014), has been reported. The cell wall degrading enzymes such as pectinase, amylase, xylanase and cellulase were produced by Fusarium sp. (Di pietro et al., 2003). In our investigation, the highest index activity of amylase was 
observed in $\mathrm{E} 15(\mathrm{H} / \mathrm{C}=4.10)$ and the lowest index activity was observed in $\mathrm{E} 7$ isolate $(\mathrm{H} / \mathrm{C}=1.53)$. Brown et al., (2001) observed that starch degrading enzymes might be indirectly responsible for pathogenecity of the fungi and $\alpha$-amylase produced by Aspergillus flavus isolates is associated with virulence of this fungal pathogen. Verlant et al., (2004) reported that the pectin methyl esterase is a pectin degrading enzymes that partially demethoxylated chains of pectin and methanol. Posada et al., (2001) investigated that polygalacturonases enzyme produced by phytopathogenic fungi helps in the process of infection and colonization in the infected host tissue. In esterase activity, the isolate E15 showed the highest activity index $(\mathrm{H} / \mathrm{C}=1.40)$ and least activity index was observed in E6 and $\mathrm{E} 19(\mathrm{H} / \mathrm{C}=1.12)$.

The all isolates of Bipolaris maydis showed a higher amylase enzymatic activity and this result revealed the potentiality of these enzymes for the invasion of plant tissues by phytopathogenic fungi.

\section{References}

Boccas, F., Roussos, S., Gutierrez, M., Serrano, L. and Viniegra, G. 1994. Fungal strain selection for pectinases production from coffee pulp in solid state fermentation system. J. Food Science Technol. 31: 22-26.

Brown, R.L., Chen, Z.Y., Cleveland, T.E., Cotty, P.J. and Cary, J.W. 2001. Variation in in vitro -amylase and protease activity is related to the virulence of Aspergillus flavus isolates. J. Food Prot. 64: 401-404.

Deising, H., Frittrang, A.K., Kunz, S. and Mendgen, K. 1995. Regulation of pectin methylesterase and polygalacturonate lyase activity during differentiation of infection structures in Uromyces viciaefabae. Microbiology.
141:561-71.

Di Pietro, A., Madrid, M.P., Caracuel, Z., Delgado-Jarana, J. and Roncero, M.I.G. (2003). Fusarium oxysporum: exploring the molecular arsenal of a vascular wilt fungus. Mol. Plant Pathol., 4: 315-326.

Dori, S., Solel, Z. and Barash, I. 1995. Cell wall-degrading enzymes produced by Gaeumannomyces graminis var. tritici in vitro and in vivo. Physiological and Molecular Plant Pathology.

Fernando, T.H.P.S., Jayasinghe, C.K. and Wijesundera, R.L.C. 2001. Cell wall degrading enzyme secretion by Colletotrichum acutatum the causative fungus of secondary leaf fall of Hevea brasiliensis. Mycological Research 105(2): 195-201. DOI $10.1017 / \mathrm{s} 0953756200003324$.

Jayasinghe, C.K., Wijayaratne, S.C.P. and Fernando, T.H.P.S. 2004. Characterization of cell wall degrading enzymes of Thanatephorus cucumeris. Mycopathologia 157(1):73-79. DOI 10.1023/b:myco.0000012210.64378.97

Kang, Z. and Buchenauer, H., 2000a. Ultrastructural and cytochemical studies on cellulose, xylan and pectin degradation in wheat spikes infected by Fusarium culmorum. J. Phytopatol., 148:263-275

Kang, Z. and Buchenauer, H., 2000b. Cytology and ultrastructure of the infection of wheat spikes by Fusarium culmorum. Mycol. Res., 104: 10831093.

Lalaoui, F., Halama, P., Dumortier, V. and Paul, B. 2000. Cell wall-degrading enzymes produced in vitro by isolates of Phaeosphaeria nodorum differing in aggressiveness. Plant Pathology 49(6): 727-733. DOI $\quad 10.1046 / \mathrm{j} .1365-$ 3059.2000.00491.x.

Martínez, M.J., Alconada, T.M., Guillén, F., Vázquez, C. and Reyes, F., 1991. 
Pectic activities from Fusarium oxysporum f.sp. melonis. Purification and characterization of an exopolygalacturonase. FEMS Microbiol. Lett., 81:145-150.

Mendgen, K., M. Hahn, H. Deising: Morphogenesis and mechanisms of penetration by plant pathogenic fungi. - A. Rev. Phytopath. 34: 367-86, 1996

Niture, S.K., Kumar, A.R. and Pant, A., 2006. Role of glucose in production and repression of polygalacturonase and pectate lyase from phytopathogenic fungus Fusarium moniliforme NCIM 1276. World J. Microb. Biotech., 22:893-899.

Posada, M. L., Patino, B., Mirete. S., Munoz, M. C., Vazquez, C. and GonzalezJaen, M.T. 2001. Comparative analysis of polygalacturonases in isolates of seven species of Fusarium from Pinus pinea. Mycol.Res.105:100-104

Sipos, B., Benkő, Z., Dienes, D., Réczey, K., Viikari, L. and Siika-aho, M. 2010. Characterisation of specific activities and hydrolytic properties of cell-walldegrading enzymes produced by Trichoderma reesei $\mathrm{C} 30$ on different carbon sources. Applied Biochemistry and Biotechnology. 161(1-8):347-364 DOI 10.1007/s12010-009-8824-4.

Ten Have, A., Mulder, W., Visser, J. N. and van Kan, A.L., 1998. The endopolygalacturonase gene Bcpg1 is required for full virulence of Botrytis cinerea. Mol. Plant-Microbe Interact., 11: 1009-1016.

Valette-Collet, O., Cimerman, A., Reignault, P., Levis, C. and Boccara, M., 2003. Disruption of Botrytis cinerea pectin methylesterase gene Bcpme1 reduces on several host plans. Mol. Plant Microbe Interact., 16, 360-367.

Verlent, I., Van loey, CA., Smout, C., Duvetter, T. and Hendriclox, ME. 2004. tomato polygalacturonase activity during thermal and high pressure treatment. Biotechnol. Bioeng. 86: 63-71.

Yang, Z.M., Bi, Y., Li, Y.C., Kou, Z.H., Bao, G.H., Liu, C.K., Wang, Y. and Wang, D. 2012. Changes of cell wall degrading enzymes in potato tuber tissue slices infected by Fusarium sulphureum. Scientia Agricultura Sinica. 45(1):127-134.

Wanyoike, W.M., Kang, Z. and Buchenauer, H., 2002. Importance of cell wall degrading enzymes produced by Fusarium graminearum during infection of wheat head. Eur. J. Plant Pathol. 108: 803-810.

Wijesundera, R.L.C., Bailey, J.A., Byrde, R.J.W. and Fielding, A.H. 1989. Cell wall degrading enzymes of Colletotrichum lindemuthianum: their role in the development of bean anthracnose. Physiological and Molecular Plant Pathology. 34(5): 403-413. DOI 10.1016/08855765(89)90067-2.

Woloshuk, C.P., Cavaletto, J.R. and Cleveland, T.E. 1997. Inducers of aflatoxin biosynthesis from colonized maize kernels are generated by an amylase activity from Aspergillus flavus. Phytopathology. 87: 164-169

Wubben, J.P., Ten Have, A., van Kan, J.A.L. and Visser, J. 2000. Regulation of endopolygalacturonase gene expression in Botrytis cinerea by galacturonic acid, ambient $\mathrm{pH}$ and carbon catabolite repression. Curr. Genetics., 37, 152- 157.

Zhang, J., Bruton, B.D. and Biles, C.L., 2014. Cell wall-degrading enzymes of Didymella bryoniae in relation to fungal growth and virulence in cantaloupe fruit. European Journal of Plant Pathology.139(4):749-761 DOI 10.1007/s10658-014-0429-2.

Zhao, Y.Q., Wu, Y.H., Fu, Y., Zhao, X.X. and 
Chen, J.G. 2014. Activity pathogenic effect of cell wall degrading enzyme in tobacco target spot pathogen Rhizoctonia solani. Tobacco Science \& Technology 11:84-88.

Zhou, S., Liu, Y., Zhang, M., Li, B.D., Chen, X.J. and Liang, W.X. 2016. Comparison of the virulence and cognate virulence factors of multinucleate, binucleate and uninucleate Rhizoctonia isolates, causing sheath blight on maize plants. European Journal of Plant Pathology 145(2): 501-506.

DOI

\section{How to cite this article:}

Nazia Manzar, Abhijeet S. Kashyap and Pawan K. Sharma. 2019. Production of Cell Wall Degrading Enzymes by Isolates of Bipolaris maydis, the Causative Agent of Maydis Leaf Blight of Maize. Int.J.Curr.Microbiol.App.Sci. 8(12): 2113-2118.

doi: https://doi.org/10.20546/ijcmas.2019.812.250 